\title{
The Influence of Family Communications on Islamic Communication Ethic at Junior High School in Medan City, North Sumatra, Indonesia
}

\author{
I. Yan Hendra ${ }^{1,2}$, Prof. Syukur Kholil ${ }^{3}$, Dr. Iskandar Zulkarnain ${ }^{4}$ \\ ${ }^{1}$ Ph.D Student at State Islamic University of North Sumatra (UINSU), Medan, Indonesia \\ ${ }^{2}$ Lecturer at University of Muhammadiyah Sumatra Utara (UMSU), Medan, Indonesia \\ ${ }^{3}$ Lecturer at State Islamic University of North Sumatra (UINSU), Medan, Indonesia \\ ${ }^{4}$ Lecturer at North Sumatra University (USU), Medan, Indonesia
}

\begin{abstract}
Family communication in the Islamic family which is conducted by parents becomes the main key in instilling the ethics of Islamic communication in children/students. The implanting of Islamic communication ethics in children is important because they are one of the Islamic power sources that will determine the future of Muslims and the preservation of Islamic teachings. Parents who have high credibility, attractiveness, power and ability to manage and deliver messages will be able to create effective the family communication. Family communication carried out by parents with an ethical basis of Islamic communication, either in terms of message content, or messages, either in the form of verbal or nonverbal and the way of communication delivered will be able to positively influence the ethics of Islamic communication of the children/students.
\end{abstract}

Keywords:Al Quran; family communication; Islamiccommunication; ethics

\section{INTRODUCTION}

Family is where a child is born and raised. In this process, parents have an obligation to nurture and educate their children, from toddlers to adults. In the teachings of Islam, children are the trust given by Allah to the parents. In carrying out this mandate, Allah commands the parents to nurture and educate the child for later salvation in the world and the Hereafter, as Allah says in At Tahrim / 66: 6.

Meaning: "O ye who believe! Take care of yourselves and your family from the fire of hell". ${ }^{1}$

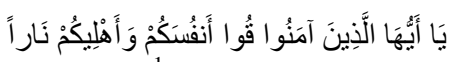

Every child of an Islamic family who is studying at a junior high school (SMP) level is one of a group of young Muslim societies. As a group that is still young, the children of Islamic families who are also the Islamic students are young Muslim generations who determine the future of Muslims and the teachings of Islam. If Muslim students can be nurtured and guided to be students who are obedient to the Islamic teachings then after their adulthood, they will be a source of Muslims strength in preserving the Islamic teachings.Caring for and educating children are inseparable from introducing, teaching and instilling ethics to them. One of the ethics taught is the ethics of Islamic communication. Islamic communication ethics which are embedded in students can be a strong fort for students. For example, students who are educated to be honest and polite will always keep themselves from bad behavior. Conversely, students who like to tell a lie will always behave naughty and not good, because they consider their behaviors will be covered with lies. The description of the Islamic communication ethics among SMP students is seen from a survey of one of the Islamic families in Medan. One parent reveals that her child's communication ethic is sometimes unfavorable. When he is advised or scolded, the child tends to fight it. It is seen from his habit of saying with a loud tone when being advised. Not only that, poor communication is seen from the rude speech, mocking or insulting his brother. The result is often misunderstanding, quarrels between them. The fighting attitudes on the children/students are also shown with less polite gestures (nonverbal communication). The description of Islamic communication ethics of SMP students is also known from the interviews with one of the SMP teachers in Medan. He said that generally his students' ethics are quite good. This can be seen from the etiquette and courtesy when speaking with the teachers, but there are still some students who have poor ethics. This can be seen when there are violations cases of the school rules, often the factor is the lack of courtesy when talking to their friends. Quarrels and fights

${ }^{1}$ Q.S. At Tahrim/ 66: 6. 
between students at school are often triggered by a lack of ethics when communicating, for example dirty and rude remarks, mocking and insulting friends. ${ }^{2}$

The lack of children/students' Islamic communication ethics in the family can be traced through a review of the existence of parents as the communicators in family communication. The low credibility of parents, lack of attractiveness, power and lack of ability in managing communication messages will cause the parents' communication becomes ineffective, conversely if parents perceived children/students as the communicators who have credibility, attractiveness, power and able to manage the message well then communication will be effective. The better the quality of these communication factors, they will be able to make a positive contribution in influencing the ethics of Islamic communication of children/students. Along with the hope that family communication can form the students into ethical students of good Islamic communication, in fact there are still many Islamic students whose ethical communication is not good. Expectations on family communication can inculcate the Islamic communication ethics in the students is not fully realized properly. From this fact, of course they raise the questions of the existence of parents as the communicators in family communication.

\subsection{Theory of Cognitive Psychology}

\section{METHODOLOGY}

Theoretically, the influence of family communication on the children/students' Islamic communication ethics can be explained by using a theory that explains the emergence of human behavior. In this study, the influence of family communication on Islamic communication ethics of students is explained by using the theory of cognitive psychology. This theory views human behavior is inseparable from the process of thinking that helped to determine human behavior. George Miller believes that cognitive psychology is a step back to commonsense, that psychology must be related to mental and behavioral life. ${ }^{3}$ The opinions about cognitive psychology also are suggested by Kurt Lewin, HeiderFestinger and the other authors. They state that cognitive psychology views humans as being active in organizing and processing stimuli. The emergence of attitudes and human behavior through a process that begins from a person's knowledge or cognition, then the knowledge is manipulated through activities of remembering, understanding, assessing, analyzing, reasoning, and speaking. ${ }^{4}$

Based on the theory, it can be stated that the behavior of communication or the children/students' Islamic communication ethics do not appear suddenly, but through thinking processes that occur in the children/students, that is thinking of something that has been experienced. In this case, the experience is family communication. Through the process of thinking, then it is obtained knowledge and awareness. The knowledge gained is then manipulated through the process of remembering, understanding, judging, analyzing, reasoning and then speaking.

In everyday life, the children/students are always faced with a picture of communication behavior either verbal or nonverbal ethical or unethical communication. The description of the communication behavior is, one of them, in the family communication. The description of communication behavior that has been experienced by the children/students is a stimulus that has been obtained through communication. All the communication events that have been experienced are knowledge and experience for the children/students.

When the family communication occurs, the children/students take notice and receive the message delivered by the parents. Attention to the message is not only limited to the content of the messages, but also the way of the messages delivered (ethical or unethical), voice tones, nonverbal cues and so on. The message is then followed in the cognition (thinking process) that produces knowledge. Knowledge is then manipulated through activities of remembering, understanding, judging, analyzing, reasoning, and language. All these processes occur in the mind (cognition) and mental (psychic) of the students.

\subsection{Family Communications}

Family life is bound by relationships among the family members. Relationships within the family can be viewed from the dimensions of blood and social relationships. The family in the dimension of the blood relationship is a unity that is bound by relationships or blood ties between each other. While in the dimension of social relationships, the family is a unity that is bound by the existence of interconnected or interacts and affects each other even though among them there is no blood relationship. ${ }^{5}$

Almost every day parents interact with their children. This interaction is made possible by the process of delivering messages among the fellow family members, especially between the parents with the children both

\footnotetext{
${ }^{2}$ Interview with MrErwin Harahap, a teacher of SMP SwastaPrayatnaon 10 September 2016.

${ }^{3}$ BimoWalgito, Teori-TeoriPsikologiSosial, (Yogyakarta: Andi Offset, 2011), p. 54.

${ }^{4}$ Jalaluddin Rakhmat, Psikologi Komunikasi (Bandung: Remaja Rosdakarya, 1996), p. 26-30.

${ }_{5}^{5}$ SyaifulBahriDjamarah. PolaKomunikasiKeluarga (SebuahPerspektifPendidikanIslam, (Jakarta: RinekaCipta 2004), p.16. 
in the form of interpersonal communication and group communication. The communication uses either verbal or nonverbal symbols that occur directly face to face. Communication occurs to form a relationship or symbiosis in the family. With regard to this, Galvin points out that family communication is as a symbiosis, the transactional process of creating and sharing meaning in the family. ${ }^{6}$

Communication that takes place in the family generally has a goal that is more directed to the education aspect. This happens when parents, a father or a mother, carry out their responsibilities in educating the child. What parents say when communicating with their children has educational value. Through family communication there are a number of norms to be instilled by the parents to their children. The norms are the norms of religious, morals, social, ethical, and aesthetic. ${ }^{7}$ Since the beginning, Islam has affirmed the position of parents as the main factor that most play a role in the development of the child's life. In this case the Prophet Sallallaahu 'wasallam has said:

"When the child is born in its nature, it is their parents who make them Jews, Christians, and/or majusi", 8

The words of the Prophet affirmed the importance of parenting role in nurturing and educating in order to form the children of sholeh, noble attitude, smart and clever.In the process of family communication, parents are more likely to occupy a position as a communicator, while the child is more as a communicant. The position of the parent as a communicator in the family communication allows him or her to influence the child. The power of communication influence that is owned by parents to the children must be supported by many factors. In this study, the influence power is seen from the quality of the parents as a communicator (credibility), attractiveness, power and also the contents of communication (message) delivered to the children and how to deliver the messages to the children.

Credibility as one of the effective communication factors has been proven by Kelman and Hovlan. Through their research, they found that the message conveyed by the communicators who have high credibility will be more reliable than the same message delivered by the communicators who have low credibility. Meanwhile the appeal of communicator is possibly made by the physical attractiveness and the similarity between the communicator and the communicant. ${ }^{9}$

Physical attractiveness is proved to have the power of influence. Generally we are more interested in people who physically look beautiful, handsome, and neat. The attraction is also made possible by the similarity. M. Roger says that communication will be more effective in the situations of hemophilic conditions, such as social, economic, cultural, communal, communist and communal attitudes compared to heterothallic situations, such as the differences in social status,economic, cultural, habits between the communicator and the communicant.Related to the effectiveness of interpersonal communication, De Vito puts forward five important aspects that must be considered and displayed by the communicators to build effective interpersonal communication. The five aspects are: openness, empathy, supportiveness, positiveness, and equality. ${ }^{10}$

\subsection{Islamic Communication Ethics}

Understanding the Islamic communication ethics can be done by understanding in advance about Islamic communication. Islamic Communication is a system of communication of Muslims based on Al-Quran and Hadith. This understanding shows that Islamic communication is more focused on the system with a philosophical background (theory) that is different from the perspective of non-Islamic communication. Islamic Communication is the process of delivering messages among people based on Islamic teachings. This understanding shows that Islamic communication is a way of Islamic communicating (Not against the Islamicteachings). ${ }^{11}$ The existence of ethics in a society will determine the survival of the community. A philosopher named S. Jack Odell says "A society without ethics is a society that is about to die." According to himthe ethical principles are a necessary prerequisite for the existence of a social community. Without ethical principles it is impossible for a human to live in harmony and without fear, anxiety, despair, disappointment, understanding and uncertainty. ${ }^{12}$

\footnotetext{
${ }^{6}$ Galvin, KM, Bylund, CL \&Brommel, BJ, Family Communication: Cohesion and Change (6th ed.), (New York: Pearson Education, 2004), p 52.

${ }^{7}$ Djamarah.PolaKomunikasi, h. 37.

${ }^{8}$ Abdul MajidKhon, HadisTarbawi (Hadis-HadisPendidikan), (Jakarta: KencanaPrenada Media Group, 2014) p, 241.

${ }^{9}$ Rakhmad, Psikologi Komunikasi, p. 262.

${ }^{10}$ Josep A De Vito, Komunikasi Antar Manusia. Terj. Agus Maulana SMS (Jakarta: Profesional Books, 1997), p. 259-263.

${ }^{11}$ A. Muis, Komunikasi Islam, (Bandung: RemajaRosdakarya, 2001), p.65.

${ }^{12}$ RichardL.Johannesen, EtikaKomunikasi, edDedyDjamaluddin MalikdanDeddyMulyana, (Bandung: RemajaRosdakarya, 1996), p. 6. 
In Al-Quran there are communication principles as a guide as well as the ethics in communicating. The principles of such communication in practice become the Islamic communicationethics. The Islamic communicationethics consist of: Qaulan Ma'rufan (Good Saying), Qawlan Kariman (HonorableSaying), Qawlan Maysuran (Easy Saying),Qawlan Balighan (Saying that kept in soul), Qaulan Layyina (Soft Saying), Qawlan Sadida (True Saying). ${ }^{13}$

\section{a. QawlanMa'rufan (Good Saying)}

Etymologically the word ma'rufan means al-khair or al-ihsan, which means good. JalaluddinRakhmat explains that QawlanMa'rufan means good saying. The words of QawlanMa'rufan one of them is contained in Al-Quran Surah An-Nisa verse 5, which means:

"And do not you give up to those who are not yet perfectly minded, the treasures (those in your power) whom Allah has made as the subject of life. Give them shopping and clothing (from the treasure) and speak to them in good saying ". 14

It is further said that QawlanMa'rufan means useful talk, giving knowledge, enlightening thoughts, showing troubleshooting. To the weak, if we cannot help materially, we must provide psychological help. In everyday life we are often faced with various problems, where in solving the problem, it requires patience and humility which are reflected from the selection of words that are adapted to the situation and environmental conditions.

\section{b. QawlanKariman (The Honorable Saying)}

The verse contains a suggestion to a child not to say the word "ah" to both parents and also shall not justify yelling at parents. According to the linguist, qaulankariman contains the noble meaning or the best according to its object. The above verse demands that what is conveyed to both parents is not only true and correct, but must also be the best and noblest. ${ }^{15}$ Hamkainterpretesqaulankarimanas encourage sayingthat causes excitement. $^{16}$

\section{c. QawlanMaysuran (Easy Saying)}

The dynamics of communication among the people in everyday life is always marked by the effective communication and the ineffective communication. In this regard, Islam provides guidance to create effective communication by saying easy or simple saying(qaulanmaysuran) when communicating. QaulanMaysuran contained in Al-Quran Surah Al-Israa verse 28, which means:

"And if you turn away from them to obtain mercy from your God whom you expect, Say unto them a simple saying". 17

QawlanMaysuran, according to JalaluddinRakhmat actually is more precisely meant "pleasant saying", which means easy, sinmple, lightweight. QawlanMaysuran contains exciting things. When we communicate, we do not only convey the content, we also define the social relationships between us. Islam forbids any communication that sets people apart and hates Allah's servants. ${ }^{18}$

\section{d. Qawlan Balighan (Saying that Kept in Soul)}

Communication effectiveness is determined by many factors, one of which is the message. The good messages one of them is a message that is easy to understand, understood and can touch the heart/feelings of the message recipients. In Islamic teachings it is commanded to speak effectively (qaulanbalighan). Speaking effectively is determined by an effective message, a message that has the power to touch the heart or soul.The word of QaulanBalighan is contained in Al-Quran Surah An-Nisa verse 63, which means:

"They are the ones that Allah knows what is in their hearts. Therefore turn away from them, and teach them a lesson, and say unto them a saying unto their souls.

The word balighan consists of the letters $b a$ ', lam, and ghain. The language expert states that all words consisting of these letters imply that something comes to something else. It also means "enough" because

\footnotetext{
${ }^{13}$ MafriAmir,EtikaKomunikasi Massa DalamPandangan Islam, (Jakarta: Logos, 1999), p. 84.

${ }^{14}$ Q.S. An-Nisaa/4: 5.

${ }^{15}$ UjangSaefullah, KapitaSelektaKomunikasi: Pendekatan Agama danBudaya, cet.2 (Bandung:

SimbiosaRekatama Media, 2013), p. 88.

${ }^{16}$ Hamka, Tafsir Al-Azhar, (Jakarta: PustakaPanjimas, 1999), p. 63.

${ }^{17}$ Q.S. Al-Israa/17. 28

${ }^{18}$ Mafri,Etika, p. 89. 
sufficiency implies reaching something to the required limits. A person who is able to string words and be able to convey his message well and simply named baligh. Mubaligh is someone who sends enough news to others.

\section{e. Qaulan Layyina (Soft Saying)}

Islam teaches Muslims to speak softly (qaulan layyinan) The words of Qaulan Layyinan are contained in Al-Quran Surat Thaha verse 44, which means:

"Then you speak to both with soft saying, May they remember or fear".

Speaking softly is the command of Allah to Moses and Aaron who would face Fir'aun to deliver the verses of Allah. Allah could actually command His apostles to say to Fir'awn in instructive or loud, but that is not the best way of achieving communicative outcomes against a person, let alone a tyrannical king. Allah commanded Moses and Aaron to commune with Fir'aun gently. This is an effective communication trick that Islam teaches. Communicating must be performed gently, without emotion, let alone berating people who want to be taken to the right path. ${ }^{20}$

\section{f. QawlanSadidan (True Saying)}

Qaulan Sadidanis mentioned twice in the Qur'an, namely in Surah An-Nisaayat 9 which means:"And should fear of Allah, those who should leave behind those weak children, whom they fear for (their welfare). Therefore let them fear of Allah and let them saying the truth ".

Qaulan sadidan means the right, honest, straight, not lying, and not convoluted sayings. The first principle of communication according to the Qur'an is saying the truth. There are several meanings of right understanding in accordance with the Qur'anic truth criterion. One of them is in accordance with the criterion of truth. For other people, the right speech, certainly the words that are in accordance with the Qur'an, sunnah, knowledge. The Qur'an states that true saying is a prerequisite for greatness. ${ }^{21}$

\subsection{Research Approach}

This research uses quantitative approach. This quantitative approach uses the data in the form of numbers and qualitative data are changed in the form of numbers (quantized). The data in the form of numbers are then analyzed by using statistical tests. Statistical tests are used to test the research hypothesis, whether accepted or rejected. This type of research is explanatory research that aims to explain the relationship between variables through hypothesis testing. Hypothesis testing used a simple regression test.

\subsection{Population and Sample}

The population of this research is the students of junior high school (SMP) either public or private schools who are Moslem in Medan City. This population selection is based on the assumption that they are generally at the end of their early teens, i.e. between 14-15 years old. They generally are in the IX class of SMP. Their common characteristics, one of which is relatively more mature than the children who began to enter early adolescence aged 11-13 years, more courageous in actualizing himself and also more intense communicate.

The determination of the research sample is conducted in stages. The first stage is determiningthe school sample. Because the school sample is homogeneous and divided into two, namely public and private schools, then from all public and private SMP schools in Medan, only 6 (six) SMP schools, that is 3 (three) public schools and 3 (three) private schools as the samples. The determination of the school sample is conducted purposively based on the division of Medan City area.

1) East of Medan City = SMP SwastaPrayatna

2) Central part of Medan City = SMP Negeri 12

3) West part of Medan City = SMP Negeri 7

4) North of Medan City = SMP Negeri 42

5) South East part of Medan City = SMP SwastaBinaBersaudara

6) Southern part of Medan city= SMPSwastaDharma Pancasila

After conducting $g$ the sampling of the school, then in the second phase is determining the number of student samples. Based on the data in each school sample is known the number of population of 6 (six) schools as many as 1104 people. Based on this population number then to determine the number of sample students used Taro Yamane formula with a precision of $5 \%$ with $95 \%$ confidence level. After processing the data with Taro Yamane formula obtained sample size of 294 students.

\footnotetext{
${ }^{19}$ M. QuraishShihab, Tafsir Al-Misbah (Pesan, Kesan, danKeserasian al-Quran. (Jakarta: LenteraHati, 2002), p. 595-596.

${ }^{20} \mathrm{Ibid}$.

${ }^{21}$ UjangSaefullah, KapitaSelekta, p. 68.

DOI: 10.9790/0837-2206044148 $\quad$ www.iosrjournals.org $\quad 45 \mid$ Page
}




\subsection{Data Collection Techniques}

The data were collected by using research instrument in the form of questionnaire. How to compile a research questionnaire through the steps are as follows:

1) Determining the indicator of the variable $X$ i.e. Family Communications and variable $Y$ i.e.the students' Islamic communication ethics

2) Determining the type of questionnaire to be used, ie a closed questionnaire.

3) Assigning the weight of the value of the alternative answer in the questionnaire. The positive value items for all variables are scored 1 to 5

4) Constructing the instrument/questionnaire grid which includes the number of items from each variable.

5) Conducting test validity and reliability questionnaire.

\subsection{Data Analysis Technique}

The research data were collected by using a closed questionnaire with Likert scale. After the data collected, then the data identification from each research variable are conducted. The identification of data is conducted through data coding of each research variable in tabulation form. Through this tabulation then the calculation to get the value of each variable is conducted.Then, conducting the influence of $\mathrm{X}$ variable that is family communications to $\mathrm{Y}$ variable that is the stduents' Islamic communication ethics. After the value of each research variable, then hypothesis is conducted.

\section{a. Hypothesis Testing}

The research hypothesis isas follows:

"The family communication has a significant effect on the Islamic communication ethics of SMP students in Medan city".

To test the hypothesis first formulated the hypothesis and the alternative hypothesis as follows:

- $\mathrm{H}_{0}=$ There is no significant effect of the family communication on the Islamic communication ethics of SMP students in Medan city.

- $\mathrm{H}_{\mathrm{a}}=$ There is a significant effect of the family communication on the Islamic communication ethics of SMP students in Medan city.

Furthermore, the criteria of rejection and acceptance of the hypothesis are as follows:

- Reject $\mathrm{H}_{0}$ if the probability value $\leq$ from the significant level is 0.05 ( $\left.\mathrm{Sig} . \leq \alpha_{0.05}\right)$

- Accept $\mathrm{H}_{0}$ if the probability value ?from the significant level of 0.05 (Sig. $\leq \alpha_{0.05}$ )

Hypothesis testing is based on the probability values obtained through the data processing. To know the calculated probability value can be seen in Table Coefficients obtained from the data processing using SPSS program version 22 as follows:

Tabel: 1

\begin{tabular}{|l|l|l|l|l|l|c|}
\hline \multicolumn{2}{|l|}{ Coefficients $^{\text {a }}$} & \multicolumn{2}{l|}{ Unstandardized Coefficients } & $\begin{array}{l}\text { Standardized } \\
\text { Coefficients }\end{array}$ & t & \multirow{2}{*}{ Sig. } \\
\cline { 3 - 5 } \multicolumn{2}{|l|}{ Model } & $\mathrm{B}$ & Std. Error & Beta & & \\
\hline \multirow{2}{*}{1} & (Constant) & 3,698 & 5,747 & &, 643 &, 520 \\
\cline { 2 - 7 } & $\mathrm{x} 1$ &, 398 &, 074 &, 285 & 5,373 &, 000 \\
\hline
\end{tabular}

Based on the data in the above table it is known that the probability value (sig) is 0.000 , so it is known that the value of $\mathrm{Sig}_{\cdot 0.000}<\alpha_{0.05}$ because the value of $\mathrm{Sig} \cdot{ }_{0.000}<\alpha_{0.05}$ then $\mathrm{H}_{0}$ is rejected and $\mathrm{H}_{\mathrm{a}}$ is accepted. The conclusion is "There is a significant influence of the family communication on students' Islamic communication ethics."

\section{DISCUSSION}

The following discussion of the research results based on the statistical analysis results in the form of hypothesis testing using SPSS program version 22. The hypothesis Testing proves there is a significant influence of the family communication on the students' Islamic communication ethics. This proof is shown by the probability value (sig) that is 0.000 , where this value is $<$ from the significant level of 0.05 ( $\mathrm{Sig}$. $\leq \alpha 0.05$ ). Because sig value < than $\alpha .05$ then there is a significant influence of the family communication to the student's Islamic communication ethics. After knowing the existence of significant family communication influence on the students' Islamic communication ethics, then it will discuss the value of the family communication coefficient $(\mathrm{X})$ to the student's Islamic communication ethics (Y). Based on the table of regression coefficients using SPSS version 22 it was obtained the value of coefficient of 0.398 , this value means that the family communication (X) has a positive effect on the students' Islamic communication ethics (Y). The value also means that, the 
contribution of family communication (X) to the students' Islamic communication ethics (Y) is 0,398 . This positive value indicates if the quality of the family communication $(\mathrm{X})$ is improved, then the student's Islamic communication ethics (Y) will increase. The results of this study, especially referring to the acceptance of the hypothesis, namely "Theb family communication has a significant effect on the students' Islamic communication ethics", this is in accordance with the theory presented by Santrock about the role of parents in the child's life. He says that parents play an important role in helping the child's development. The development of the child's personality and child's behavior cannot be separated from the ways of managing the lives of children conducted by parents in the family. ${ }^{22}$ The influence of parents on the child has also been raised by the Prophet s.a.w in his saying:

\section{"Each child was born in his nature, it is his parents who made him a Jew, a Christian, and / or} a majusi."

The influence of family communication on the students' Islamic communication ethics cannot be separated from the credibility of parents as communicators in family communication, this proves the truth of the communicatorstheory put forward by Carl Hovland and Walter Weiss. They say that the communicators who are able to influence the communicant effectively are determined by what they call credibility communicator consisting of two elements: expertise and trustworthy. ${ }^{23}$ Besides proving the truth of the theory about the credibility of communicators, the influence of family communication on the students' Islamic communication ethics prove the truth of the interpersonal communication theory as proposed by De Vito about the five important aspects that support the success of intepersonal communication namely openness, empathy, supportive attitude, positiveness, and equality (interpersonal family communication). This study shows the involvement of the five elements in the family communication with children/students. Besides proving the truth of the theory, this study also proves the truth about the effectiveness of communication messages theory which is designed and structured well by Wilbur Schramm who is famous for the concept of "the condition of success in communication," a condition that must be met if we want a message to arouse our desired responses.The conditions are formulated by Schramm as follows:

1) Messages should be designed and delivered in such a way, so that it attracts the attention of the communicant.

2) The message must use symbols aimed at the same experience between the communicator and the communicant, so that both can understand.

3) The message should arouse the personal needs of the communicant and suggests several ways to obtain those needs.

4) The message should suggest a way to obtain the appropriate need for a group situation in which the communicant is at the moment he is moved to provide the desired response.

\section{CONCLUSION}

Based on the results of this study it can be put forward some conclusions as follows:

1. Family communication affects the Islamic communication ethics of the children/students of SMP Medan City. The influence is shown by the contribution of teh family communication of 0.398 units to the students' Islamic communication ethics. Family communication has a positive effect on the students' Islamic communication ethics. The better the family communication to the children/students then the better the students' Islamic communication ethics.

2. The influence of family communication on the students' Islamic communication ethicsis caused by the communication factors involved in the family communication process consisting of: credibility, attractiveness and power possessed by the communicator. In addition, it is also made by a communication message that includes the messages content, message design and how to deliver the message to the communicant.

3. The theories about cognitive psychology/human behavior, including the emergence of communication behavior caused by the environmental factors and thinking processes that are mental processes, are still validated as a factor affecting human behavior/communication behavior.

\section{REFERENCES}

[1] Al-Quran danTerjemahnya. Al-Muyassar, (Bandung: SinarBaruAlgensindo, 2012).

[2] Amir, Mafri.EtikaKomunikasi Massa DalamPandangan Islam, Jakarta: Logos, 1999.

\footnotetext{
22 John W Santrock, PerkembanganAnak, ed. 11, terj.MilaRachmawatidan Ana Kuswanti, (Jakarta: Erlangga, 2007), p. 164

${ }^{23}$ Rakhmat.PsikologiKomunikasi, p. 256

DOI: 10.9790/0837-2206044148 $\quad$ www.iosrjournals.org $\quad 47 \mid$ Page
}


[3] De Vito, Josep A. Komunikasi Antar Manusia, terj Agus Maulana MSM, Jakarta: Profesional Books, 1997.

[4] Djamarah, Syaiful Bahri. Pola Komunikasi Keluarga (Sebuah Perspektif Pendidikan Islam), Jakarta: Rineka Cipta 2004.

[5] Effendy, OnongUchjana..Ilmu, TeoridanFilsafatKomunikasi, Bandung: Citra AdityaBakti, 2003.

[6] Galvin, KM, Bylund, CL \&Brommel, BJ, Family Communication: Cohesion and Change, 6th ed. New York: Pearson Education, 2004.

[7] Johannesen, Richard L. EtikaKomunikasi, edDedyDjamaluddin Malik danDeddyMulyana, Bandung: RemajaRosdakarya, 1996.

[8] Khon, Abdul Majid, HadisTarbawi (Hadis-HadisPendidikan), Jakarta: KencanaPrenada Media Group, 2014.

[9] Muis, A, Komunikasi Islam, Bandung: RemajaRosdakarya, 2001.

[10] Rakhmad, Jalaluddin. Psikologi Komunikasi, Bandung: Remaja Rosdakarya, 1996.

[11] _ MetodePenelitianKomunikasi: DilengkapiContohAnalisisStatistik, Bandung: RemajaRosdakarya, 2007.

[12] Saefullah, Ujang. KapitaSelektaKomunikas: PendekatanBudayadan Agama, cet. 2, Bandung: SimbiosaRekatama Media, 2013.

[13] Santrock, John W. PerkembanganAnak, ed. 11, terj. Mila Rachmawatidan Ana Kuswanti, Jakarta: Erlangga, 2007.

[14] Shihab, M. Quraish, Tafsir Al-Misbah (Pesan, Kesan, danKeserasian al-Quran. Jakarta: LenteraHati, 2002.

[15] Singarimbun, MasridanSofian Effendi.MetodePenelitian Survey, Jakarta: LP3ES, 1989.

[16] Walgito, Bimo, Teori-TeoriPsikologiSosial, Yogyakarta: Andi Offset, 2011. 